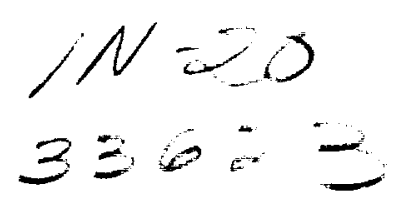

NASA Technical Memorandum 105190

AIAA-91-3484

227

\title{
Design Issues for Propulsion Systems Using Metallized Propellants
}

Bryan Palaszewski

National Aeronautics and Space Administration

Lewis Research Center

Cleveland, Ohio

and

Douglas Rapp

Sverdrup Technology, Inc.

Lewis Research Center Group

Brook Park, Ohio

Prepared for the

Conference on Advanced Space Exploration Initiative Technologies cosponsored by the AIAA, NASA, and OAI

Cleveland, Ohio, September 4-6, 1991
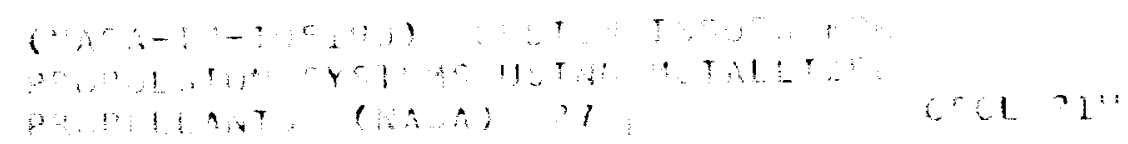


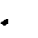


Design Issues For Propulsion Systems Using Metallized Propellants

\author{
Bryan Palaszewski*, ** \\ National Aeronautics and Space Administration \\ Lewis Research Center \\ cleveland, OH \\ Douglas Rapp** \\ Sverdrup Technology, Inc. \\ NASA Lewis Research Center Group \\ Brook Park, OH
}

\begin{abstract} Metallized propellants are liquid
propellants that contain metal
particles. These particles are
suspended in a gelled fuel or oxidizer. Aluminum is used as the metal additive. The addition of metal to conventional propellants can increase their specific impulse and their density over conventional propellants, and consequently, the payload delivered on Mars and lunar transportation vehicles, Earth-toorbit vehicles and upper stages for robotic planetary missions. Gelled fuels also provide increased safety during accidental propellant leakage or spills. To take full advantage of these performance increases, there are changes that must be made to the vehicle design. This paper will discuss the differences between metallized propellants and traditional liquid propellants and their effect on the propulsion system design. These differences include the propellant density, mixture ratio, engine performance and propellant rheology. Missions related to the Space Exploration Initiative are considered as design examples to illustrate these issues. The propellant combinations that were considered were $\mathrm{O}_{2} / \mathrm{H}_{2} / \mathrm{Al}$, $\mathrm{O}_{2} / \mathrm{RP}-1 / \mathrm{Al}$ and NTO/MMH/A1.
\end{abstract}

Nomenclature

Al

$\mathrm{Al}_{2} \mathrm{O}_{3}$

$\mathrm{C}_{3}$

$\mathrm{C}_{\mathrm{f}}$

DOD

ETO

$\mathrm{H}_{2}$

IRFNA

$I_{\mathbf{s p}}$

$\mathbf{K}$

LEO

LMO

LRB

MEV

MR

MTV
Aluminum

Aluminum Oxide

Injection Energy

Thrust Coefficient

Department of Defense

Earth-to-Orbit

Hydrogen

Inhibited Red Fuming Nitric Acid

Specific Impulse

$\left(1 b_{f}-s / 1 b_{m}\right)$

Consistency Index

Low Earth Orbit

Low Mars Orbit

Liquid Rocket Booster

Mars Excursion Vehicle

Mixture Ratio

Mars Transfer Vehicle

* Program Manager, Metallized Propellant Program

** AIAA Member 


$\begin{array}{ll}\text { n } & \text { Flow Behavior Index } \\ \text { NASA } & \begin{array}{l}\text { National Aeronautics and } \\ \text { Space Administration }\end{array} \\ \text { NTO } & \text { Nitrogen Tetroxide } \\ \text { MMH } & \text { Monomethyl Hydrazine } \\ \text { MW } & \text { Molecular Weight } \\ \text { O }_{2} & \text { Oxygen } \\ \text { Pc } & \text { Chamber Pressure } \\ \text { RP-1 } & \text { Rocket Propellant-1 } \\ \text { SCE } & \text { Space Chemical Engine } \\ \text { SRB } & \text { Solid Rocket Booster } \\ \text { STS } & \text { Space Transportation } \\ \text { STS-C } & \text { System } \\ \text { TMace Transportation } & \text { System-Cargo } \\ & \text { Chamber Temperature } \\ \text { Trans - Mars Injection } & \text { Stage }\end{array}$

Greek Symbols

$\begin{array}{ll}\Delta V & \text { Velocity Change }(\mathrm{km} / \mathrm{s}) \\ \epsilon & \text { Expansion Ratio } \\ \eta & I_{3 p} \text { Efficiency }\end{array}$

\section{Introduction}

In the Space Exploration Inftiative (SEI, Ref. 1), the Moon and Mars, as well as other parts of the solar system, are potential sites for exploration and economic development. Human and robotic missions for SEI will require large transportation vehicles, typically with extremely- large space propulsion systems (Refs. 1 through 5). Propulsion is a major part of the mass and the cost of any exploration mission. Because it is a large cost factor, ways to reduce the propulsion system cost or improve the mission effectiveness with "better" propulsion are sought. Increasing the mission safety or increasing the payload, or both, are some of the ways of improving effectiveness.

Many propulsion technologies are available for future space missions. Selecting the "best" technology will be based upon it's level of technical performance, safety, risk, cost and ability to meet the project's schedule. While advanced solar-, nuclear-electric and nuclear-thermal propulsion systems are contenders for some aspects of SEI, chemical propulsion systems still remain as the preferred option for lunar and Mars excursion vehicles and for Earthto-Orbit transportation.

Trade studies conducted over the past several years (Ref. 1 through 5,7 and 8) have described a wide range of propulsion technology improvements that will enhance the SEI missions. One potential liquid propulsion technology improvement is called metallized propellants. In this paper, a set of design issues will be addressed that must be analyzed during the selection process. Examples of some of the studies that should be conducted prior to making a propulsion system selection are provided.

\section{Background}

A chemical propulsion option for an SEI application will be drawn from the past or planned flight systems or from the many technologies being investigated in current national programs. With high-thrust chemical propulsion, the major contenders in the selection are liquid, solid and 
hybrid (1iquid-solid) propulsion. One type of liquid propulsion uses metallized propellants. Metallized propellants are gelled liquid propellants that contain suspended metal particles. Aluminum was chosen because it has a high combustion energy, it is easy to handle and because there has been extensive combustion testing conducted with it in past programs. The liquid propellant is gelled with an additive that is a very small fraction of the total propellant mass. Typically, the metal is in the form of micron-sized particles. These propellants have the ability to increase engine specific impulse, increase propellant density and increase system safety.

The specific impulse ( $I_{\text {ap }}$ ) of a rocket engine is proportional to:

$$
I_{s p} \propto\left(T_{c} / M W\right)^{1 / 2}
$$

where:

$\begin{array}{ll}T_{c} & \text { Chamber Temperature } \\ \text { MW } & \begin{array}{l}\text { Molecular Weight of } \\ \text { Combustion Products }\end{array}\end{array}$

Because of increases in combustion temperature, or reductions in the molecular weight of the exhaust products, or both, the $I_{s p}$ of the metallized propulsion system is increased (Refs. 5 and 7 through 13). The increases in propellant density reduce the tankage mass as well as the overall propulsion system dry mass. Because many of the propulsion system elements are dependent on the propellant mass and volume, the propellant density can have a large effect on the overall dry mass. Reductions in dry mass can also allow increases in delivered payload.

Safety is another important advantage of metallized propellants (Ref. 6).
Because the aluminum is gelled with the fuel, the gel prevents widespread spillage of the propellant if it were released. Cleanup of the spill is easier because the spill is restricted to a more confined area. As part of the Department of Defense (DoD) development of insensitive munitions, gelled and/or metallized propellants became an important option for making propellants safer (Ref. 6). Leakage is reduced or made more controllable with metallized propellants because It is gelled. The safety of the propulsion system is improved by reducing the leakage rate. During a leak, the fuel will leave the propellant tank but the leak is slowed by the high viscosity of the fuel. Also, the gel makes the propellants less sensitive to high-energy particles that penetrate the propellant tank. If a projectile penetrates the propellant tank (such as a micrometeoroid, a wrench dropped during ground assembly, space debris, etc.), the gel propellant will prevent a catastrophic explosion.

\section{Performance Benefits For Future Missions}

Piloted missions to Mars can derive several benefits from using metallized propellants. For the expedition- and evolution-class Mars missions (Refs. 2 and 7), a $25,000-\mathrm{kg}$ payload was delivered to the Martian surface. The Mars engines used a 1000-psia chamber pressure and 500:1 expansion ratio for the transfer vehicle and 200:1 for the excursion vehicle. The vehicle's mass in Low Earth Orbit (LEO) was over $1,000,000 \mathrm{~kg}$. Using metallized $\mathrm{O}_{2} / \mathrm{H}_{2} / \mathrm{Al}$, the $\mathrm{I}_{\mathrm{sp}}$ can be increased by $51 b_{f}-s / 1 b_{m}$ (60-percent Al loading in $\mathrm{H}_{2}$ ) over $\mathrm{O}_{2} / \mathrm{H}_{2}$ and 20 to 22 percent additional payload to the surface can be sent to Mars (Ref. 7). Therefore, fewer flights are needed to deliver the same payload and the flight schedule can be reduced by 20 to 22 
percent. A shortening of the total program flight schedule is afforded by the improved vehicle performance. By delivering more payload per mission, the total cost of the transportation system and the program is reduced. After multiple Mars flights, this schedule reduction translates into substantial launch cost reductions (for multiple Space Transportation System-Cargo [STS-C] or other Earth-to-Orbit vehicles) and savings of many years of assembly time for these Mars missions (Ref. 7).

Propellants such as NTO/MMH/AI and $\mathrm{O}_{2} / \mathrm{MMH} / \mathrm{Al}$ can provide Earth- and space-storable options for a Mars ascent stage of a manned Mars excursion vehicle. Metallized NTO/MMH/Al increases the $I_{\text {sp }}$ by up to $251 b_{f}-s / 1 b_{m}$ over an NTO/MMI system. The higher boiling point of these propellants either minimizes or eliminates propellant boiloff losses. The mass penalty for using these propellants over oxygen/hydrogen $\left(\mathrm{O}_{2} / \mathrm{H}_{2}\right)$ is minimal: an additional 3 to 5 percent of the vehicle's initial mass in LEO (Ref. 7).

A lunar mission using metallized $\mathrm{O}_{2} / \mathrm{H}_{2} / \mathrm{Al}$ propellants (60-percent $\mathrm{Al}$ loading) was considered in Reference 8. The lunar transfer vehicle engines used a 1000-psia chamber pressure and 1000:1 expansion ratio. By increasing the $I_{\mathrm{sp}}$ by $6 \quad 1 b_{\mathrm{f}}-\mathrm{s} / 1 \mathrm{~b}_{\mathrm{m}}$, the added payload delivered to the lunar surface is modest: 2 to 3 percent (Ref. 8 ). Because the lunar mission has a smaller total velocity change $(\Delta V)$ than the Mars mission, the total payload benefit is substantially smaller. This option does not demonstrate a large gain for metallized propellants, but the lunar mission might be used as a test bed for future more ambitious Mars missions where metallized systems have much greater payload leverage.
With upper stages propelling robotic planetary missions, metallized $\mathrm{O}_{2} / \mathrm{H}_{2} / \mathrm{Al}$ and $\mathrm{NTO} / \mathrm{MMH} / \mathrm{Al}$ have very significant potential, especially for high-energy fast planetary missions (Ref. 9). On an outer planet flyby, metallized propellants for an STS-C compatible upper stage can deliver 28 percent more injected mass onto a planetary trajectory (with an injection energy $\left(C_{3}\right)$ of $\left.150 \mathrm{~km}^{2} / \mathrm{s}^{2}\right)$. For a Jupiter orbiter mission, an upper stage using NTO/MMH/Al can deliver 97 percent more injected mass than NTO/MMH (at a $C_{3}$ of $80 \mathrm{~km}^{2} / \mathrm{s}^{2}$ ).

For Earth-to orbit vehicles, metallized $\mathrm{O}_{2} / \mathrm{RP}-1 / \mathrm{Al}$ and NTO/MMH/Al propellants allow significant payload increases for volume constrained booster stages (Ref. 10). An option to consider is a replacement of the Space Transportation System (STS) Solid Rocket Boosters with metallized liquid rocket boosters. The payload increases are 14 to 35 percent over the baseline payload of $22,527 \mathrm{~kg}$ $\left(49,664 \quad 1 b_{m}\right)$. These sTS payload increases can be used for support of lunar and Mars missions. Crew capsules, payloads, flight and assembly crews for SEI may be delivered to LEO using the STS.

An integral aspect of metallized propellants is the fact that they are gelled liquids. These gels are thixotropic and non-Newtonian and the propellant feed system must be designed to provide the propellants with the same control as with Newtonian fluids. Some of the issues that must be considered in designing metallized feed systems and tankage are discussed later in the paper.

The formulation of metallized propellants requires the addition of thickening agents, or gellants, to suspend the solid metallic aluminum powder within the liquid fuel carrier. 
Without gellants, the denser aluminum $\left(2700-\mathrm{kg} / \mathrm{m}^{3}\right)$ would settle out of the less dense liquid fuel (for example, normal bolling point liquid hydrogen has a density of $70.77 \mathrm{~kg} / \mathrm{m}^{3}$ ). Generally, gellants are long-chained molecules that create a three-dimensional, semi-rigid structure within the liquid carrier to "lock in" the metal particulates. The structure is usually formed through either weak chemical bonding (eg. hydrogen-bonding) or simple 1iquid adsorption by the intermeshed, high-surface-area gellant particles. Due to the presence of this gel structure, gelled metallized propellants have unique static and flow properties in comparison to their pure liquid counterparts.

\section{Current Programs}

The technologies for metallized propellants have been investigated for many years both at NASA and the DoD (Refs. 11, 12 and 13). The current efforts at NASA and the DoD are increasing our knowledge of and reducing the risk of using metallized propellants by proving the technology with small- and large-scale demonstrations.

The NASA program has focused on two propellant combinations: oxygen/Rocket Propellant-1/aluminum $\left(\mathrm{O}_{2} / \mathrm{RP}-1 / \mathrm{Al}\right)$ and oxygen/ hydrogen/aluminum $\left(\mathrm{O}_{2} / \mathrm{H}_{2} / \mathrm{Al}\right)$. These two have wide application to future missions in both space vehicle and Earth-to-Orbit propulsion. The DoD programs, however, are emphasizing Earth-storable propellants, such as inhibited red fuming nitric acid/monomethyl hydrazine/aluminum (IRFNA/MMH/A1). A DoD propulsion system would typically require storage for long periods of time with minimal processing prior to firing. Therefore, a storable propellant is almost a necessity. Using these DoD-developed technologies on NASA missions is an
Important option being considered in the NASA Metallized Propellant Program. This is because Earth storable (NTO/MMH/AI) combinations will provide significant benefits for several NASA mission options.

\section{Design Issues With}

\section{Metallized Propulstion Systems}

All of these benefits of metallized propellants are derived only if several changes are made to the existing designs of chemical propulsion systems. It is not possible to simply place metallized propellants into the tankage of an existing vehicle and gain all of the potential performance benefits. The mafor changes are to the engine, the vehicle tankage and the propellant feed system. The major elements that control the vehicle design are the metal loading and the non-Newtonian nature of gelled propellant. The succeeding sections will discuss some of the trade studies that should be considered while making a selection of the "best" design for a metallized propulsion system. Aspects such as the metal loading effects upon the engine mixture ratio and the vehicle tankage, the engine $I_{s p}$ efficiency effects upon the delivered payload, and the changes to the engine combustion temperature will be addressed.

\section{Metal Loading and Performance}

One of the most significant changes that must occur with metallized engines is the reduction of the engine mixture ratio. With the addition of metal to the fuel, the mixture ratio drops from 6.0 with $\mathrm{O}_{2} / \mathrm{H}_{2}$ to 0.7 to 3.2 for $\mathrm{O}_{2} / \mathrm{H}_{2} / \mathrm{Al}$ propellants (Refs. 7 and 10). The range of mixture ratio is dependent upon the metal loading of the fuel (Refs. 7 to 10). The most obvious change in the vehicle using metallized propellants will be in the tankage size. Due to the reduction in 
propellant mixture ratio, the oxidizer and fuel tankage volumes will typically differ from the nonmetallized cases. Because a smaller mass of oxidizer is required, the oxidizer tank will shrink. However, the fuel tank may increase or decrease in size, depending on the metallized fuel density.

\section{Mars Missions}

In selecting the "best" design point for metallized propulsion systems, the mass and volume of the propellant tanks may vary substantially over a range of metal loadings. Figure 1 presents the volume variation of $\mathrm{O}_{2} / \mathrm{H}_{2} / \mathrm{Al}$ propellant tankage for the Trans-Mars Injection stage of a expedition-class Mars mission (Ref. 7). A similar analysis is provided in Figure 2 for the expedition-class Mars Excursion Vehicle (MEV). Table I lists the $I_{3 p}$ and mixture ratio for each of the metal loadings of the MEV, Mars Transfer Vehicle (MTV) and the TMIS. As shown in Figures 1 and 2 , the volume variation with the metal loading is not a smooth function between the 60 and 70 percent metal loadings. The sharp increases in volume are caused by the non-linear relation between the mixture ratio and the fuel density increase. In the lower mixture ratio system, a larger fraction of the propellant mass is fuel. The fuel density is also increasing as the mixture ratio drops, but the increased fuel density does not fully counterbalance the volume increase due to the dropping mixture ratio. The result is the unusual nonlinear variation in the tankage mass. The tankage volume increases significantly in the regions of 62 and 66-percent metal loading. As the $I_{s p}$ increases, the mixture ratio (MR) drops. This MR decrease increases the $\mathrm{H}_{2} / \mathrm{Al}$ fuel tank volume. The density of the fuel does increase as the $\mathrm{Al}$ loading increases, but not enough to allow the volume to monotonically increase. As the MR increases, the fuel density goes up and the volume begins to drop. This drop is most prominent between a metal loading of 62 to 65 and 66 to 70 percent.

Figure 3 provides the corresponding LEO Initial mass of the metallized $\mathrm{O}_{2} / \mathrm{H}_{2} / \mathrm{Al}$ Mars vehicle and the vehicle using $\mathrm{O}_{2} / \mathrm{H}_{2}$ propulsion. The variation in the initial mass of the Mars vehicle (In the range 62 to 66 percent metal loading) is small but the tankage volume, shown in FIgures 1 and 2 , may vary over a large range. In Figure 2, at a metal loading of 40 percent, the total MEV tank volume required is $61.9 \mathrm{~m}^{3}$. At 70 percent loading, a $66.6-\mathrm{m}^{3}$ volume is needed: a 7.6-percent increase. Also, with the TMIS, the volume variation from 40 to 70 percent is a 6.3 -percent increase. The maximal TMIS volume increase was 10.44 percent (from a 40 -percent to a 66-percent metal loading). This volume variation over a small metal loading range can have an important influence on the packaging of the MEV and the other Mars propulsion systems aboard an Earth-to-Orbit (ETO) vehicle. Additional consideration must be given to addressing the tankage volume while conducting detailed trade studies of metallized propellants.

While investigating the volume variations for the Mars vehicles, it is important to note that the payload increases are the highest for the higher metal loadings. The maximal payload increases that are possible with metallized $\mathrm{O}_{2} / \mathrm{H}_{2} / \mathrm{Al}$ are presented in Figure 4. At a 70 -percent metal loading, the payload increase is 33 percent over $\mathrm{O}_{2} / \mathrm{H}_{2}$. This is a significant improvement over the payload increase of 22 percent for a 60 -percent metal loading. Beyond a 70 - 
percent metal loading, the metallized $I_{\text {sp }}$ begins to fall and the payload mass begins to decrease.

\section{Lunar Missions}

Based on the results of the Mars analysis, other higher metal loadings for lunar vehicles were investigated. Because the lunar engine design parameters are very similar to those of a Mars mission, the same type of selection criteria may be applicable. The lunar mission analyses in Ref. 8 described the point design performance for a 60-percent metal loading in $\mathrm{O}_{2} / \mathrm{H}_{2} / \mathrm{Al}$. This performance is based on an improvement of the technologies in the Space Chemical Engine (SCE) Technology Program at NASA (Ref. 14). Figure 5 shows the payload capability of the lunar cargo mission with differing metal loadings. At a 70 percent metal loading, the payload gain is increased to 5.5 percent over $\mathrm{O}_{2} / \mathrm{H}_{2}$ propulsion. This is still only a modest payload increase (1485 kg) over the baseline $27,000-\mathrm{kg}$ lunar payload. Later in the paper, other analyses of the potential performance penalties of metallized propellants for lunar missions will be discussed.

\section{Earth-to-Orbit Vehicles}

Selecting the "best" metal loading for an ETO vehicle may depend on the configuration of the system. Based on the analyses of the STS using metallized propellants, (Ref. 10), the highest $I_{\text {sp }}$ system is often not the "best" design point for an ETO vehicle. The importance of propellant density is most notable when trying to fit within the already existing volume constraints of a flight vehicle.

Figure 6 shows the variation of the $S R B$ length with metal loading for $\mathrm{O}_{2} / \mathrm{RP}-1 / \mathrm{Al}$. In Ref. 10 , the metal loading of 55 percent was selected based on a preliminary trade studies of the metal loading that would provide the maximal payload. Further sensitivity analyses showed that the LRB could be further shortened by increasing the metal loading. At a 65percent metal loading, the LRB length would be shortened to $141.4 \mathrm{ft}$. This is only $0.9 \mathrm{ft}$ shorter than that previously estimated (Ref. 10). Thus the 55-percent Al loading is a nearoptimal metal loading.

With $\mathrm{O}_{2} / \mathrm{H}_{2} / \mathrm{Al}$ propellants, the LRB length was not compatible with the SRB length: the booster was over $300 \mathrm{ft}$ tall (Ref. 10) and was significantly longer than the $149-\mathrm{ft}$ SRB. A sensitivity analysis, shown in Figure 7 , revealed that over the range of 50 to 70-percent metal loading, the LRB length was still substantially longer than the SRB: 270 to $311 \mathrm{ft}$ long. The optimization was able to find a shorter booster, but the design constraints still could not be met. A future $\mathrm{O}_{2} / \mathrm{H}_{2} / \mathrm{Al}$ booster that does not have the tight volume constraints of the STS SRB, however, may be able to provide a significant payload benefit for Earth-to-Orbit vehicles

\section{Upper Stages}

Figures 8 and 9 show the performance of upper stages launched with the STS$C$. The upper stages are designed for robotic missions with a $C_{3}$ of 15 $\mathrm{km}^{2} / \mathrm{s}^{2}$, using the design data and criteria provided in Reference 9. In Figure 8 , the metallized $\mathrm{O}_{2} / \mathrm{H}_{2} / \mathrm{Al}$ and the $\mathrm{O}_{2} / \mathrm{H}_{2}$ stage have very similar performance levels. Only an additional 338 to $366 \mathrm{~kg}$ (or 1.3 to 2 percent) of added injected mass are delivered with $\mathrm{O}_{2} / \mathrm{H}_{2} / \mathrm{Al}$ (with a 60-percent $\mathrm{Al}$ loading). In this case, metallized propellants are not an attractive option. With the storable stages shown in Figure 9, metallized propellants are potentially very attractive. The injected mass increases with 
NTO/MMH/AI are 10.3 to 17.5 percent (1940 to $1790 \mathrm{~kg}$ ) over the NTO/MMH.

Upper stage packaging can also be an important consideration in such volume-Iimited cargo bays as the STSC. Table II compares the tank volumes for upper stages using $\mathrm{O}_{2} / \mathrm{H}_{2}$, metallized $\mathrm{O}_{2} / \mathrm{H}_{2} / \mathrm{Al}$, storable NTO $/ \mathrm{MMH}$ and metallized NTO/MMH/Al. With the metallized $\mathrm{O}_{2} / \mathrm{H}_{2} / \mathrm{Al}$ upper stage, the volume of the stage increases only 0.3 percent over the non-metalized propellant stage. On the metallized storable propellant stage, however, the total tankage volume is reduced by 17.4 percent.

\section{Specific Impulse Efficiency (n) Performance Influence}

The influence of $\eta$ on the performance of the metallized propulsion systems for various missions was investigated. Due to the two-phase flow of the metallized propellants in the combustion chamber and nozzle, there is a difference between the gas and solid-liquid particle velocities which creates a performance loss. The solidliquid particles are composed of solid and liquid aluminum oxide $\left(\mathrm{Al}_{2} \mathrm{O}_{3}\right)$. Once the potential losses of metallized propellants are introduced into the analysis, the performance may be much lower than that previously predicted. A series of cases showing this influence on the $\mathrm{O}_{2} / \mathrm{H}_{2} / \mathrm{Al}$ and NTO/MMH/Al systems were analyzed and the results are discussed below.

\section{Mars and Lunar Missions}

The potential payload increases predicted for Mars missions using metallized propellants will only be enabled if very high $\eta$ is possible. Figure 10 depicts the payload capability of a Mars mission with $\mathrm{O}_{2} / \mathrm{H}_{2} / \mathrm{Al}$ propellant for a range of $\eta$. The maximum $\eta$ is 0.984 (Ref. 7). Once $\eta$ falls below 0.967 , the payload of the metallized Mars vehicle is less than that of $\mathrm{O}_{2} / \mathrm{H}_{2}$ propulsion.

A simflar analysis is shown for a large lunar cargo mission (Ref. 8). On the lunar missions, the $\eta$ influence on payload is depicted in Figure 11 . When the $\eta$ drops below 0.97 , the metallized LTV is no longer able to deliver the $27,000-\mathrm{kg}$ payload mass.

\section{Upper Stages}

With $\mathrm{O}_{2} / \mathrm{H}_{2} / \mathrm{Al}$ stage in the STS-C, the performance for planetary missions shows a small 1.3- to 2-percent benefit over $\mathrm{O}_{2} / \mathrm{H}_{2}$ when the mission $C_{3}$ is between than 0 and $30 \mathrm{~km}^{2} / \mathrm{s}^{2}$. This benefit is possible assuming that the $\eta$ for both propulsion systems is equal: 0.984 . As the $\eta$ drops, only the missions with very high injection energies will derive a benefit from metallized propellants (Ref. 9). Because of the small benefit enabled with metallized propellants, they are not recommended as an option for the low-energy planetary missions. Further analysis of this case was not conducted.

The overall effect of reduced $\eta$ is less detrimental for NTO/MMH/Al propellants. With the metallized NTO/MMH/Al, the theoretical $I_{s p}$ increase over NTO/MMH is $25 \mathrm{lb}_{\mathrm{f}}-\mathrm{s} / 1 \mathrm{~b}_{\mathrm{m}}$. This large increase is able to "absorb" a larger I penalty than the other metallized propellant cases and still enable a large injected mass increase. An $\eta$ range of 0.888 to 0.938 represents up to a 5-percent penalty on $\eta$ (Refs. 15 and 16). Figure 12 shows the effect of reduced $\eta$ on the mission with a $C_{3}$ of $15 \mathrm{~km}^{2} / \mathrm{s}^{2}$. The NTO/MMH $\eta$ is 0.938 . Even if the $\eta$ is reduced to 0.895 , the NTO/MMH/Al stage can still deliver the same injected mass as the NTO/MMH stage. Once the $\eta$ drops below 0.895 , the metallized system is not able to provide an injected mass increase over NTO/MMH. 
Clearly, the $\eta$ will have a very strong influence on reducing the injected mass performance in some of the metallized cases. A penalty of the magnitude predicted for metallized propellants can potentially eliminate their benefits. Small reductions in the $\eta$, however, can be absorbed with only a small payload penalty. Research on reducing the performance losses of metallized systems has been conducted (Ref. 16). Reducing the $\mathrm{Al}_{2} \mathrm{O}_{3}$ particle size has been shown to reduce the gas and solid-liquid velocity differences, improve the metallized $\eta$ and thus improve the delivered payload.

\section{Engine Combustion Temperatures}

The engine combustion temperatures for metallized combinations are often significantly different over nonmetallized propellants. The differences could lead the engine designer to consider concepts such as oxidizer cooling or higher temperature materials such as iridium/rhenium for combustion chamber materials. Several examples of the combustion temperatures for differing engine applications are provided below.

\section{Mars and Lunar Missions}

Table III lists the temperatures and other design aspects of the Mars mission engines (70-percent metal loading). The MTV, TMIS and lunar engine parameters are not shown. This is because their characteristics are nearly identical to the MEV engines, save for the larger $c$ of 500:1 for the MTV and TMIS and 1000:1 $\epsilon$ of the lunar engines. For the $\mathrm{O}_{2} / \mathrm{H}_{2} / \mathrm{Al}$ engines of the Mars and lunar vehicles, the combustion temperatures are lower than those for the $\mathrm{O}_{2} / \mathrm{H}_{2}$ engines: $426 \mathrm{~K}$ lower. The molecular weight of the exhaust, however, has been reduced and therefore provides a higher $I_{3 p}$. This lower combustion temperature may prove very beneficial for increasing engine
IIfe and make the engine cooling of a metallized engine more tractable.

\section{Upper Stages}

Table IV contrasts the combustion temperatures and other design parameters for $\mathrm{O}_{2} / \mathrm{H}_{2}$ and $\mathrm{O}_{2} / \mathrm{H}_{2} / \mathrm{Al}$ upper stage engines (60-percent metal loading). As discussed above, the metallized combustion temperature has dropped slightly over the $\mathrm{O}_{2} / \mathrm{H}_{2}$ engine. In Table $v$, a similar comparison is presented for NTO/MMH and NTO/MMH/Al. With these metallized engines, the combustion temperature has increased by $513 \mathrm{~K}$. These engines may require more unusual cooling techniques to achieve the desired performance. If these temperatures are not acceptable, a different metal loading may be used as an option to reduce the combustion temperature.

\section{Earth-to-orbit}

At the engine design points for LRBs, the results with $\mathrm{O}_{2} / \mathrm{H}_{2} / \mathrm{Al}$ are similar. Table VI compares $\mathrm{O}_{2} / \mathrm{H}_{2} / \mathrm{Al}$ and $\mathrm{O}_{2} / \mathrm{H}_{2}$ for the LRB. The combustion temperature is $426 \mathrm{~K}$ lower with the metallized engine (70-percent metal loading). Because the LRB metal loading is the same as that for the Mars engine design, the engine design conditions are comparable.

With $\mathrm{O}_{2} / \mathrm{RP}-1 / \mathrm{Al}$, the metallized combustion temperature, shown in Table VII, is $472 \mathrm{~K}$ higher than the nonmetallized engine. The higher combustion temperature of the RP-1/Al system may demand operation at different metal loadings if an acceptable cooling method is not found. As shown in Figure 6 , the $\mathrm{O}_{2} / \mathrm{RP}-1 / \mathrm{Al}$ booster length variation with metal loading is minimal over a wide range of metal loadings. Operating at a different metal loading will reduce these potentially high temperatures. Cooling methods will 
have to be investigated to determine the best mix of materials and new engine design to accommodate metallized propellants.

\section{Metallized Propellant Rheology}

Propellant rheology must be addressed to correctly design the different flow elements of a rocket engine feed system. In the succeeding sections, the types of design analyses that must be conducted are discussed. These design analysis issues are related to propellant slosh, propellant residuals, feed system lines and the unique characteristics of gelled metallized propellants. While a specific feed system was not analyzed, the discussion touches on some of the specific characteristics that must be designed into the feed system hardware and into the propellant itself.

\section{Propellant Viscosity}

Some rheological classifications of fluids are graphically illustrated in Figure 13 as viscosity versus $10 \mathrm{~g}$ shear (flow) stress under isothermal conditions. Both Newtonian and non-Newtonian fluids have temperature-dependent viscosities; however, unlike Newtonian fluids which have constant viscosities under isothermal conditions, non-Newtonian fluids have variable viscosity under different shear conditions.

Gelled metallized propellants often exhibit a yield, pseudoplastic flow behavior (Figure 13). The yield stress is indicative of the strength of the semi-solid gel structure within the liquid carrier and exhibits an infinite viscosity at static and low-shear-stress conditions. This yield-stress feature of gelled metallized propellants can reduce the slosh of the propellant within the vehicle's tanks (Ref. 17). Yield stresses are not, however, excessive in magnitude (typically $<2000$ dynes $/ \mathrm{cm}^{2}$ for metallized propellants) so that large shear stresses are not required to break the yield stress. When the driving shear stress on the metallized propellant exceeds the yield stress, the gel structure breaks down and the metallized propellant begins to flow. Pseudoplastic, or shear thinning, flow behavior results. The viscosity decreases under increasing shear stress until some final limiting Newtonian viscosity is achieved. Physically, this reduction in viscosity can be envisioned as the gradual breakdown of the gel structure and the subsequent alignment of the long gellant particles in the direction of flow. With pseudoplastic fluids, the shear thinning is reversible; the viscosity will increase with decreasing shear rate along the same shear path as that previously followed under increasing shear.

This shear thinning effect of metallized propellants can be time-dependent as well. Shown in Figure 14, viscosity continually decreases with increasing time at a constant applied shear stress; this flow behavior is termed thixotropy. Upon removal of the driving shear force, the thixotropic fluid begins to relax and recover its gel structure. Some thixotropic fluids will not totally recover their original structure due to permanent damage to the actual gellant particles, such as the fragmentation of the original long-chained molecule thus weakening bonding strength. The time the fluid takes to fully relax and recover its original gel structure, or some reduced-strength gel structure is important in determining different regions within the flow, such as stagnant areas in velocity transition regions. The gelled metallized propellant rheology issues of yield point, shear thinning 
and gel relaxation time are addressed below with specific rocket engine flow element examples where these parameters play a major influence.

\section{Yield Point and Tank Expulsion}

The yield point of metallized propellants establishes a minimum stress required to initiate flow. Yield-point fluids will tend to adhere to propellant tank wall surfaces much more than Newtonian fluids because the flow shear at the tank walls is insufficient to break the yield stress. This adhesion must be minimized in metallized propellant tank expulsions in order to reduce propellant residuals. Propellant adhesion can be controlled by minimizing the yield stress magnitude, increasing the gravitational field imposed upon the tank and increasing the tank exit surface inclination, using a conical outlet (Ref. 18). Another solution to minimizing propellant adhesion is to formulate a gel that has an elastic, or cohesive, viscosity component in addition to the simple shear viscosity component, a viscoelastic fluid. The gelled propellant will want to pull away from the wall surface upon flow initiation (Ref. 19). This cohesive-gel solution to adhesion, however, may lead to difficulties in flowing an elastic fluid further downstream of the tank. For example, in a pump-fed system, the fluid's elasticity as well as the yield point magnitude should be minimized so that the pressure head requirements of the pump inlet are not excessive.

Beyond the adhesional influence in tank expulsion, the yield point controls the distribution of fluid exit velocity through the tank volume. Upon tank expulsion, a velocity field, or high shear stress region, is established at the exit and the metallized propellant flows out from the tank because the yield point is greatly exceeded in this region. A "coring" effect, where the fluid in the middle of the tank is expelled, was once thought to be a feed system design barrier, but earlier experimental work has demonstrated that coring and cavitation in the tank can be completely prevented by minimizing the yield point magnitude, employing the proper tank geometry design and/or utilizing a positive-displacement propellant expulsion technique (such as a diaphragm, Ref. 20).

s.

Shear Thinning and Feed System sizing

The shear thinning behavior of metallized propellants produces a fluid viscosity that is variable with shear stress (pseudoplastic) and time (thixotropy). This variability in viscosity influences pipe cross-sectional velocity profiles where the shear stress changes with pipe radius. Utilizing a power law rheological model relating shear stress, to shear rate in the form $r-K *$ (shear rate) ${ }^{n}$ to model a time-independent shear thinning fluid flow, laminar velocity profiles are illustrated in Figure 15 with varying effective flow behavior indices ( $n$ ) and constant effective consistency index (K). Newtonian, constant viscosity flow is indicated by an $n$ value of 1 . As the extent of viscosity reduction in the fluid becomes greater, ie. n smaller, the velocity profiles become flatter as the flow boundary layers become smaller. Since the entire cross-sectional flow is not fully sheared, plug flow may result. This effect is not evident in turbulent flows where the laminar sublayer is very thin and both the Newtonian and non-Newtonian velocity profiles are flat (Ref. 21). This reduction in cross-sectional flow area may have to be accounted when sizing 
and instrumenting a rocket engine feed system.

Ideally, the metallized propellant would be initially sheared down to its final limiting constant viscosity as it exits the propellant tank so that the fluid flow system could be designed for a Newtonian fluid; however, it may be difficult to maintain such a high shear rate through the whole flow circuit. Variable viscosity fluids complicate the use of conventional flow meters and flow controllers which rely on a constant Newtonian viscosity to operate on a pressure drop versus flow rate curve. If the metallized propellant is shear thinning with no time dependency, this variance in viscosity may be calibrated into the flow meters. For example, using the same power law model above, volumetric flow rate versus pressure drop curves can be produced for varying $n$ and constant $K$. These curves are plotted in Figure 16. Pressure drop clearly decreases with decreasing effective flow behavior index, $n$. However, if the viscosity is time-dependent, then the pressure drop is difficult to predict. One solution to variable viscosity effects on flow meters and flow controls is the use of a Corlolis-force mass flow meter in feedback loop control with the driving flow source, le. tank pressurant, or pump. A Coriolis-force mass flow meter measures the change in frequency of a vibrating flow tube in which the metallized propellant flows in relation to a reference frequency. This difference is correlated with mass flow rate and may be fed back to the flow controller to adjust the driving flow source to a particular operating condition.

\section{Relaxation Time and Propellant Accumulations}

The major issue with the rheological parameter, relaxation time, is the build- up of metallized propellant in flow passages where a velocity transition exists. Some examples of these velocity transition areas are converging-diverging flow passages, elbows and turbomachinery passages. When the fluid flow slows down or stops, the viscosity of the fluid begins to simultaneously increase through a reconstruction of the gel structure. If the relaxation time is short, the gel structure w11l reform quickly and metallized propellant may accumulate. To minimize propellant accumulations, a long relaxation time is desired and, generally, can be formulated into the metallized propellant using a combination of flow experiments and fuel formulation parametrics.

\section{Concluding Remarks}

To take advantage of the potential benefits of metallized propellants, several significant changes to current propulsion system designs are needed. The changes influence engine performance, tankage, feed system and propellant processing. The optimal or the "best" design conditions for engine mixture ratio and metal loading should be selected using a series of mission-related studies. Each mission will define a set of engine and vehicle parameters that give the highest payload or the smallest volume or perhaps a combination of the two.

Each metallized propulsion application may have unique vehicle design aspects. With the $\mathrm{O}_{2} / \mathrm{H}_{2} / \mathrm{Al}$ systems, tankage volume may be the dominant issue, whereas engine combustion temperatures may be the most-pressing matter for $\mathrm{O}_{2} / \mathrm{RP}-1 / \mathrm{AI}$ and storable NTO/MMH/Al propellant vehicles. Because storable NTO/MMH/AI can deliver large 20 - to $25-1 b_{f}-5 / 1 b_{m}$ increases in $I_{\text {ap }}$ over NTO/MMH, it is more "tolerant" of combustion losses. 
A high $I_{\text {ap }}$ efficiency is, however, essential with the $\mathrm{O}_{2} / \mathrm{H}_{2} / \mathrm{Al}$ systems which deliver $I_{a p}$ increases of 10 to $111 b_{f}-s / 1 b_{m}$.

A significant increase in delivered payload was achieved over $\mathrm{O}_{2} / \mathrm{H}_{2}$ with metallized $\mathrm{O}_{2} / \mathrm{H}_{2} / \mathrm{Al}$ propulsion with a metal loading of 70 percent. While previous studies had focused on a 60 percent Al loading, the metal loading of 70 percent showed large improvements in payload over the 60 . percent loading performance. Payload increases of 33 percent (70-percent Al) versus the previous 20 to 22 percent increase (with 60-percent Al) are potentially important for SEI missions.

With Mars missions, the highest engine performance may require a larger vehicle volume: 6 to 11 percent more for the range of metal loadings from 40 to 70 percent. The tankage packaging and ability to fit within an existing ETO vehicle shroud may be a more pressing issue and hence performance may not be of the most critical importance. Special consideration must be taken in selecting the "correct" metal loading to fit within the volume constraints. The volume variations of the Mars vehicles points to the unique relationship between metal loading. mixture ratio and vehicle volume. These systems studies can direct the selection of the "best" vehicle performance and volume for a specific mission type.

Very high specific impulse efficiency will be of critical importance for metallized engines. A penalty of 2 percent in $I_{\text {sp efficiency will }}$ eliminate the payload advantage of metallized $\mathrm{O}_{2} / \mathrm{H}_{2} / \mathrm{Al}$ propellants for Mars missions. With storable NTO/MMH/Al, the penalty that can be accommodated is higher (4 percent), but the importance of high efficiency is still very clear. Though the payload on SEI missions may suffer somewhat due to reduced performance, the nature of gelled propellants still provides a strong added safety feature that may make them the propellants of choice.

While the $\mathrm{O}_{2} / \mathrm{H}_{2} / \mathrm{Al}$ engine offer significant reductions in combustion temperature over $\mathrm{O}_{2} / \mathrm{H}_{2}$, NTO/MMH/Al and $\mathrm{O}_{2} / \mathrm{RP}-1 / \mathrm{Al}$ require much highertemperature operation than their nonmetallized counterparts. While operating at different metal loadings to reduce the combustion temperature may be an option, new materials and refinements of existing engine cooling designs may be adequate to the task of making metallized engines operate efficiently at the metal loadings that deliver the maximum potential payload performance.

The major rheological technology issues in implementing a non-Newtonian, gelled metallized propellant are yield point, shear thinning behavior and gel relaxation time. These issues are not insurmountable and simply require adequate technology work in the proper formulation and characterization of the fuels for their specific application. Given the suitable rheological tailoring, metallized propellants offer tremendous safety advantages in addition to their density and performance benefits.

To bring metallized propellants to future missions, investments in technology are being made today. The current NASA and DoD investments in this technology are an important part of establishing the true benefits of these gelled liquid propellants. Only after adequate combustion and rheological testing have been conducted will we have sufficient information to proceed with metallized propulsion for flight systems. 


\section{References}

1) Stafford, T., et al., "America at the Threshold: America's Space Exploration Initiative," U.S. Government Printing Office, May 1991.

2) "Study Requirements Document FY 89 Studies, " NASA Office of Exploration, Document Number Z2.1-002, March 3, 1989.

3) "Report of the 90-Day Study on Human Exploration of the Moon and Mars," NASA Headquarters, November 1989.

4) "Office of Exploration Exploration Studies Technical Report, FY 88 Status," Volume II: Study Approach and Results, NASA Technical Memorandum 4075, December 1988.

5) "Analysis of Technologies for Manned Lunar and Mars Missions," Boeing Aerospace Company, NASA Contract NAS8-36107, Final Briefing, January 26, 1989.

6) Haun, D.V., et al., "Insensitive Munitions Testing of Thixotropic Gels," Talley Defense Systems, CPIA Publication 515, Volume III, presented at the 1989 JANNAF Propulsion Meeting, Cleveland, $\mathrm{OH}$, May 23-25, 1989.

7) Palaszewski, B., Metallized Propellants for the Human Exploration of Mars, "NASA Lewis Research Center, NASA TP-3062, presented at the Case for Mars IV Conference, Boulder, $\mathrm{CO}$, June 4-8, 1990 .

8) Palaszewski, B., "Lunar Missions Using Advanced Chemical Propulsion: System Design Issues," NASA Lewis Research Center, NASA TP-3065, AIAA
Paper 90-2431, presented at the 26th AIAA/ASME/SAE/ASEE Joint Propulsion Conference, Orlando, FL, July 16-18, 1990.

9) Palaszewski, B., "Advanced Launch Vehicle Upper Stages Using Liquid Propulsion and Metallized Propellants," NASA Lewis Research Center, presented at the 1990 JANNAF Propulsion Meeting, Anaheim, CA, October $3-5,1990$.

10) Palaszewsk1, B. and Powell, R., "Launch Vehicle Performance Using Metallized Propellants," NASA Lewis Research Center, AIAA Paper 91-2050, presented at the 27 th AIAA/ASME/SAE/ASEE Joint Propulsion Conference, Sacramento, CA, June 24-27, 1990.

11) Second Metallized Gelled Propellants Conference, Chemical Propulsion Information Agency (CPIA), conference held at the Air Force Rocket Propulsion Laboratory, August 26-28, 1964.

12) Smith, A. L., et al., "Propulsion Systems Hazard Evaluation and Liquid/Gel Propulsion Component Development, Volume $1^{n}$ Aerojet Techsystems, Contract Number DAAH01-86-C-0110, Technical Report CR-RD-RP-90-2, January, 1990.

13) Zurawski, R., "Current Evaluation of the Tripropellant Concept," NASA Lewis Research Center, NASA TP-2602, June 1986.

14) Hannum, N., et al., "NASA's Chemical Transfer Propulsion Program for Pathfinder," NASA Lewis Research Center, NASA Technical Memorandum 102298, AIAA Paper 89-2298, presented 
at the AIAA/ASME/SAE/ASEE 25th Joint Propulsion Conference, Monterey, CA, July 10-12, 1989.

15) Galecki, D., "Combustion and Ignition of Metalized Propeliants," NASA-Lewis Research Center, AIAA Paper 89. 2883, presented at the 25th AIAA/ASME/SAE/ASEE Joint Propulsion Conference, Monterey, CA, July 10-12, 1989.

16) Turns, S., et al, "Secondary Atomization of Aluminum/RP-1 Liquid Rocket Slurry Fuels," presented at the Eastern Section: The Combustion Institute - Fall Technical Meeting 1990, Orlando, FL, December 3-5, 1990.

17) Haun, D.V. and Ryder, D.D., "Gel Propellant Safety and Handling Characteristics, "Talley Defense Systems Inc., presented at the JANNAF Propulsion Meeting, 1987.
18) Salzwedel, R.A. and Mason, G.E. "Propellant Utilization Outflow and Adherence, "Martin-Marietta Corporation Aerospace Division, presented at the 2nd Metallized Gelled Propellants Conference, AFRPL, Edwards, CA, August 26-28, 1964.

19) Krull, H. George, "Formulation and Evaluation of the Characteristics of Metallized Gelled Propellants," The Marquardt Corporation, presented at the Metallized Gelled Propellants Conference, AFRPL, Edwards, CA, June 10-12, 1963.

20) Giola, G., et al., "Advanced Gel (AGEL) Technology Program, " TRW Inc., presented at the JANNAF Propulsion Meeting, Cleveland, OH, May 23-25, 1989.

21) Skelland, A.H.P., Non-Newtonian Flow and Heat Transfer, John Wiley \& Sons Inc., New York, 1967, Pp. 1-238. 
Table I

$\mathrm{O}_{2} / \mathrm{H}_{2} / \mathrm{Al}$ Engine Performance With Metallized Propellants:

Mars Mission

\begin{tabular}{lccc}
$\begin{array}{l}\text { Metal } \\
\text { Loading }\end{array}$ & $\begin{array}{c}I_{\text {ap }}{ }^{*} \\
\end{array}$ & $\left(1 b_{f}-\mathbf{s} / 1 b_{m}\right)$ & $\begin{array}{c}\text { Mixture } \\
\text { Ratio }\end{array}$ \\
& MEV & MTV, \\
& & TMIS & \\
& & & \\
\hline & & & \\
40 & 471.9 & 482.0 & 3.2 \\
45 & 472.5 & 482.6 & 2.8 \\
50 & 473.2 & 483.3 & 2.4 \\
55 & 474.1 & 484.2 & 2.0 \\
60 & 475.3 & 485.4 & 1.6 \\
62 & 476.9 & 486.2 & 1.2 \\
64 & 477.3 & 487.0 & 1.1 \\
65 & 477.4 & 487.3 & 1.1 \\
66 & 478.3 & 487.8 & 0.9 \\
68 & 479.1 & 488.8 & 0.8 \\
70 & 479.9 & 489.8 & 0.7 \\
& & &
\end{tabular}

$\star \eta-0.984$

Table II

Tankage Volumes Differences with Metallized Propellants: STS-C Upper Stage Application: $\mathrm{C}_{3}=15 \mathrm{~km}^{2} / \mathrm{s}^{2}$

\begin{tabular}{lcc}
$\begin{array}{l}\text { Propellant } \\
\text { Type }\end{array}$ & $\begin{array}{c}\text { Tankage } \\
\text { Volume } \\
\left(\mathrm{m}^{3}\right)\end{array}$ & $\begin{array}{c}\text { Volume } \\
\text { Reduction } \\
(8)\end{array}$ \\
\hline $\mathrm{O}_{2} / \mathrm{H}_{2}$ & 108.8 & -- \\
$\mathrm{O}_{2} / \mathrm{H}_{2} / \mathrm{Al}$ & 109.1 & -0.3 \\
NTO/MMH & 33.2 & -- \\
NTO/MMH/A1 & 40.2 & 17.4 \\
\hline
\end{tabular}

Table III

Engine Design Parameters

for $\mathrm{O}_{2} / \mathrm{H}_{2}$ and $\mathrm{O}_{2} / \mathrm{H}_{2} / \mathrm{Al}$ Propellants:

Mars Excursion Vehfcle

\begin{tabular}{lrr} 
Parameter & \multicolumn{1}{c}{$\mathrm{O}_{2} / \mathrm{H}_{2}$} & $\mathrm{O}_{2} / \mathrm{H}_{2} / \mathrm{Al}$ \\
\hline$P_{c}$ (psla) & 1000.0 & 1000.0 \\
$\epsilon$ & $200: 1$ & $200: 1$ \\
Metal Loading (8) & 0.0 & 70.0 \\
Mixture Rat1o & 6.0 & 0.7 \\
$T_{c}$ (K) & 3495.1 & 3069.1 \\
MW & 13.5 & 11.3 \\
$C_{q}(\epsilon-200: 1)$ & 1.977 & 1.984 \\
$I_{s p}\left(1 b_{q}-s / 1 b_{m}\right) *$ & 470.1 & 479.9
\end{tabular}

$\star \eta-0.984$
Table IV

Engine Design Parameters

for $\mathrm{O}_{2} / \mathrm{H}_{2}$ and $\mathrm{O}_{2} / \mathrm{H}_{2} / \mathrm{Al}$ Propellants: STS-C Upper Stages

\begin{tabular}{lrr} 
Parameter & \multicolumn{1}{c}{$\mathrm{O}_{2} / \mathrm{H}_{2}$} & $\mathrm{O}_{2} / \mathrm{H}_{2} / \mathrm{Al}$ \\
\hline $\mathrm{P}_{\mathrm{c}}$ (psia) & 1000.0 & 1000.0 \\
$\epsilon$ & $500: 1$ & $500: 1$ \\
Metal Loading (8) & 0.0 & 60.0 \\
Mixture Ratio & 6.0 & 1.6 \\
$\mathrm{~T}_{\mathrm{c}}(\mathrm{K})$ & 3495.1 & 3371.1 \\
MW & 13.5 & 12.8 \\
$\mathrm{C}_{\mathrm{f}}(\epsilon-500: 1)$ & 2.032 & 2.043 \\
$\mathrm{I}_{\mathrm{sp}}\left(1 \mathrm{~b}_{\mathrm{f}}-\mathrm{s} / 1 \mathrm{~b}_{\mathrm{m}}\right) *$ & 479.5 & 485.4 \\
${ }^{* \eta-0.984}$ & & \\
\hline
\end{tabular}


Table V

Engine Design Parameters for NTO/MMH and NTO/MMH/A1 Propellants: STS-C Upper Stages

\begin{tabular}{lrr} 
Parameter & NTO/MMH & NTO/MMH/Al \\
\hline Pc (psia) & 1000.0 & 1000.0 \\
$\epsilon$ & $500: 1$ & $500: 1$ \\
Metal Loading (8) & 0.0 & 50.0 \\
Mixture Ratio & 2.0 & 0.9 \\
$T_{c}$ (K) & 3366.3 & 3879.0 \\
MW (chamber) & 22.3 & 27.3 \\
$C_{f}(\epsilon-500: 1)$ & 1.994 & 2.156 \\
$I_{\text {ap }}\left(1 b_{f}-s / 1 b_{m}\right) *$ & 341.2 & 366.4
\end{tabular}

$\star \eta-0.938$

Table VI

Engine Design Parameters

for $\mathrm{O}_{2} / \mathrm{H}_{2}$ and $\mathrm{O}_{2} / \mathrm{H}_{2} / \mathrm{Al}$ Propellants:

IRB Application

\begin{tabular}{lrr} 
Parameter & \multicolumn{1}{c}{$\mathrm{O}_{2} / \mathrm{H}_{2}$} & $\mathrm{O}_{2} / \mathrm{H}_{2} / \mathrm{Al}$ \\
\hline $\mathrm{P}_{\mathrm{c}}$ (psia) & 1000.0 & 1000.0 \\
$\epsilon$ & $30: 1$ & $30: 1$ \\
Metal Loading (8) & 0.0 & 70.0 \\
Mixture Ratio & 6.0 & 0.7 \\
$\mathrm{~T}_{\mathrm{c}}(\mathrm{K})$ & 3495.1 & 3069.1 \\
$\mathrm{MW}$ & 13.5 & 11.2 \\
$\mathrm{C}_{\mathrm{f}}(\epsilon-30: 1)$ & 1.799 & 1.807 \\
$\mathrm{I}_{\mathrm{sp}}\left(1 \mathrm{~b}_{\mathrm{f}}-\mathrm{s} / 1 \mathrm{~b}_{\mathrm{m}}\right) *$ & 419.2 & 428.1 \\
\hline
\end{tabular}

$\star \eta=0.94$
Table VII

Engine Design Parameters

for $\mathrm{O}_{2} / \mathrm{RP}-1$ and $\mathrm{O}_{2} / \mathrm{RP}-1 / \mathrm{A} 1$ Propellants:

LRB Application

\begin{tabular}{|c|c|c|}
\hline Parameter & $\mathrm{O}_{2} / \mathrm{RP}-1$ & $\mathrm{O}_{2} / \mathrm{RP}-1 / \mathrm{Al}$ \\
\hline $\begin{array}{l}P_{c}(p s i a) \\
\epsilon \\
\text { Metal Loading (8) } \\
\text { Mixture Ratio } \\
T_{c}(K) \\
M W \\
C_{f}(\epsilon=30: 1) \\
I_{s p}\left(1 b_{f}-s / 1 b_{m}\right) *\end{array}$ & $\begin{array}{r}1000.0 \\
30: 1 \\
0.0 \\
2.7 \\
3697.2 \\
23.8 \\
1.822 \\
324.5\end{array}$ & $\begin{array}{r}1000.0 \\
30: 1 \\
55.0 \\
1.1 \\
4169.3 \\
29.1 \\
1.832 \\
317.3\end{array}$ \\
\hline
\end{tabular}




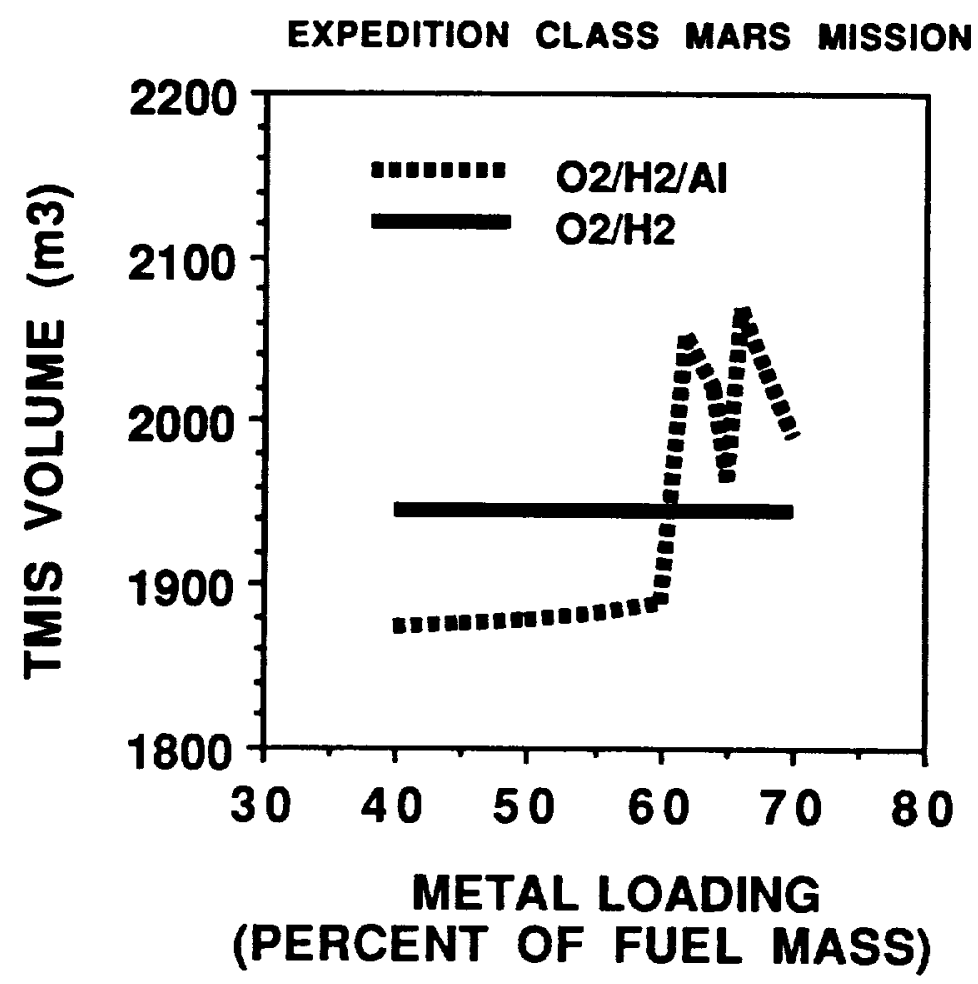

Figure 1. Trans-Mars Injection Stage Volume vs. Metal Loading

EXPEDITION CLASS MARS MISSION

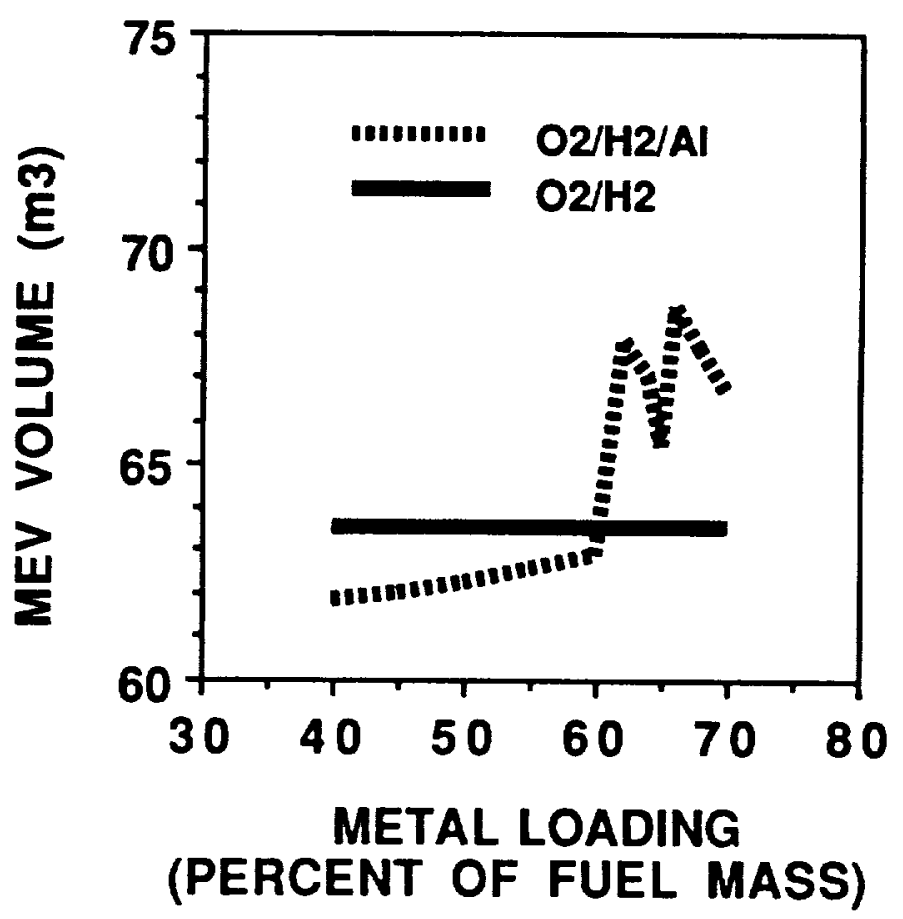

Figure 2. Mars Excursion Vehicle Volume vs. Metal Loading 


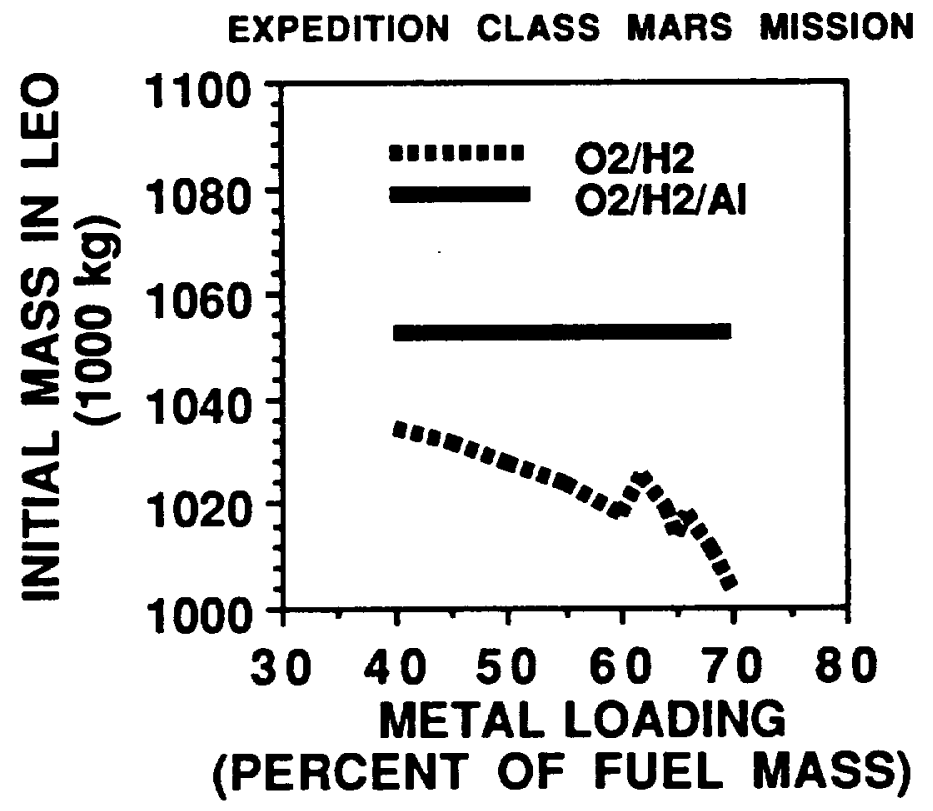

Figure 3. Mars Mission Initial Mass vs. Metal Loading

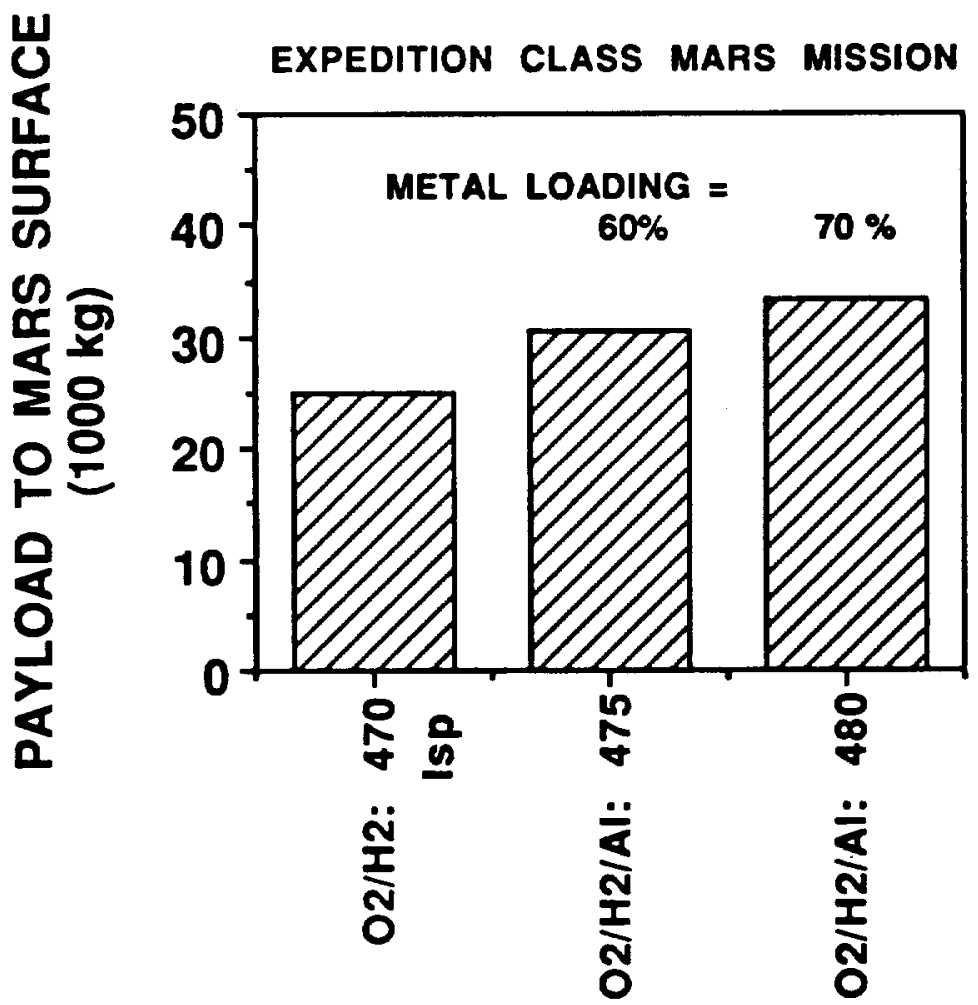

PROPULSION TECHNOLOGY

Figure 4. Payload to Mars Surface 


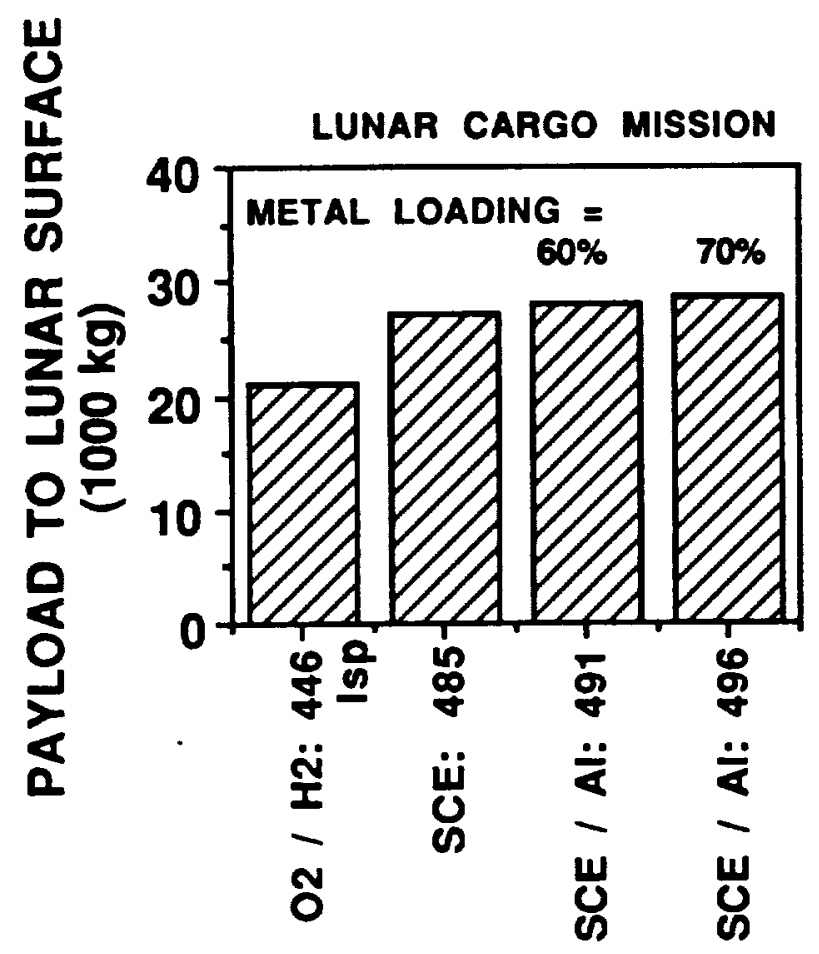

PROPULSION TECHNOLOGY

Figure 5. Lunar Excursion Vehicle Payload to Lunar Surface

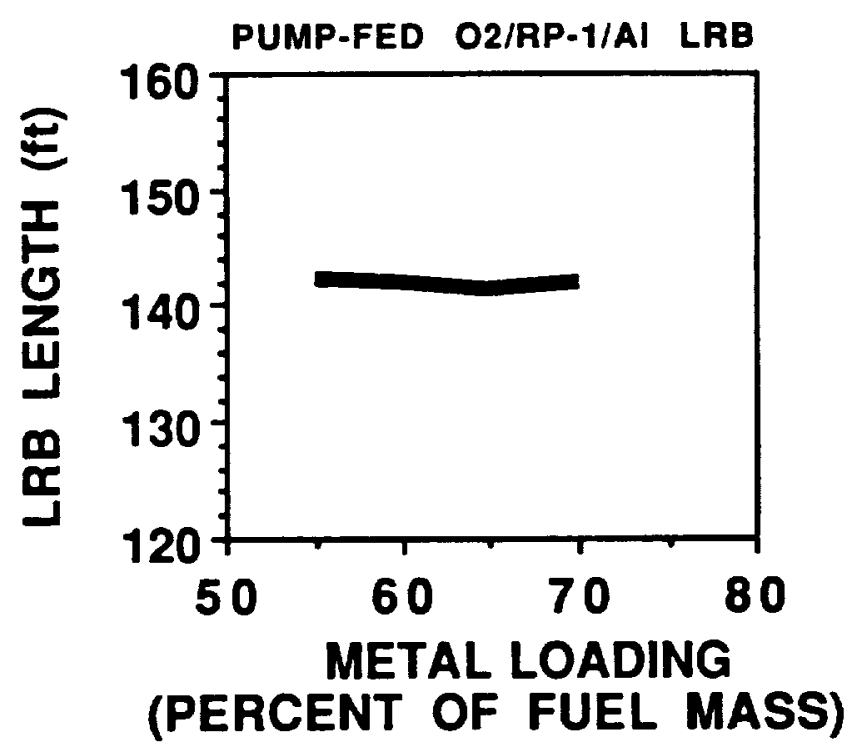

Figure 6. Llquild Rocket Booster Length vs. Metal Loading: O2/RP-1/AI 


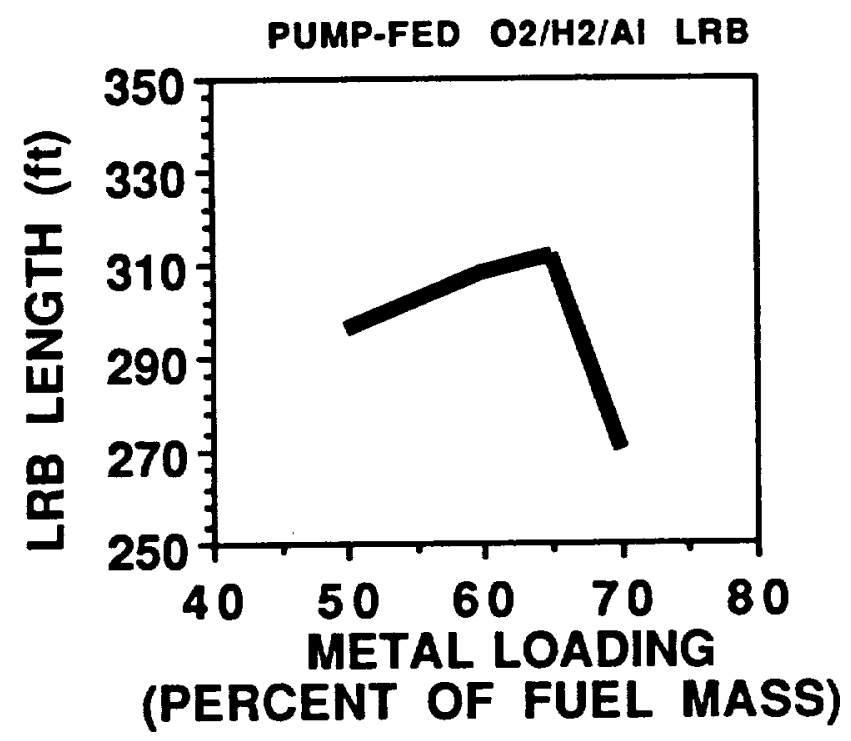

Figure 7. Llquid Rocket Booster Length vs. Metal Loading: O2/H2/AI

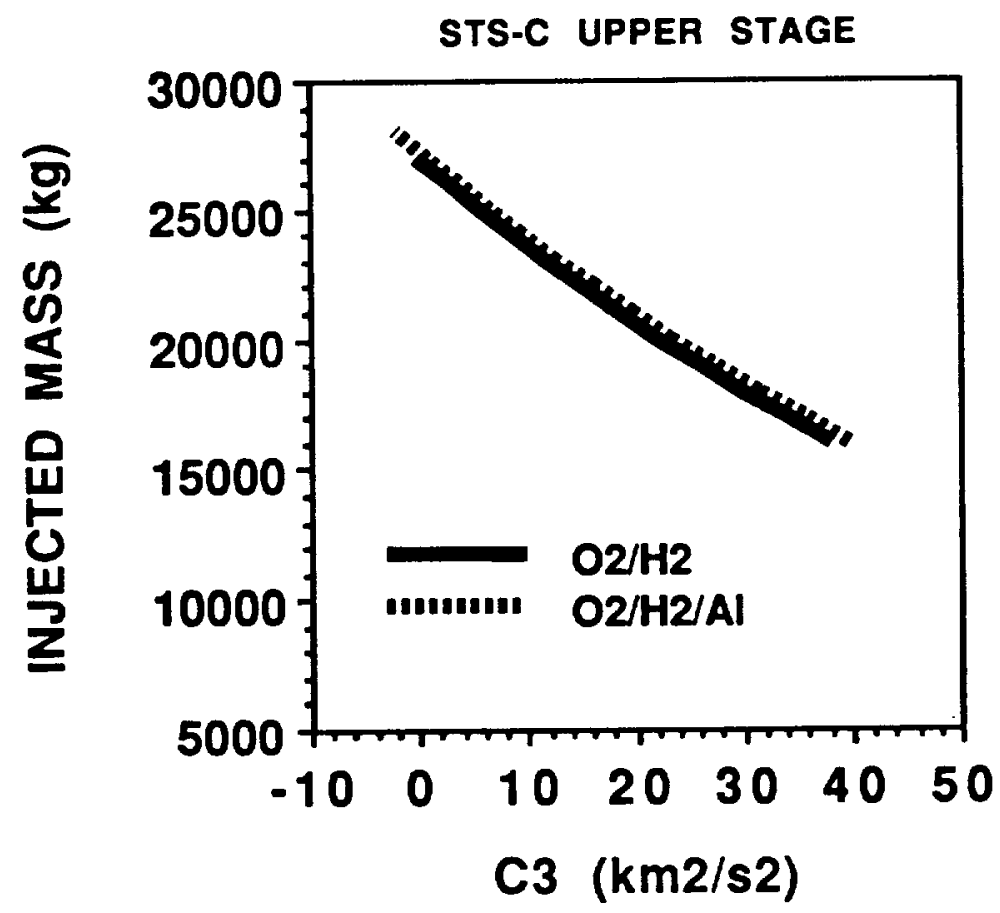

Figure 8. Injected Mass vs. C3: Cryogenic Stages 


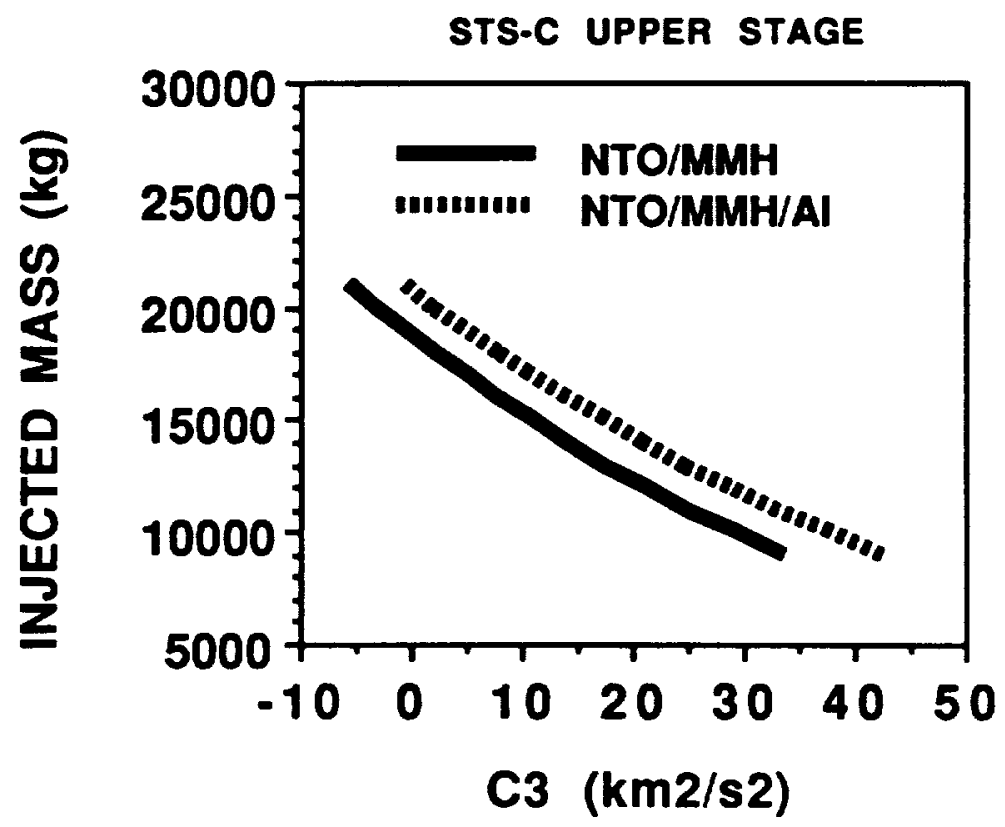

Figure 9. Injected Mass vs. C3: Storable Stages

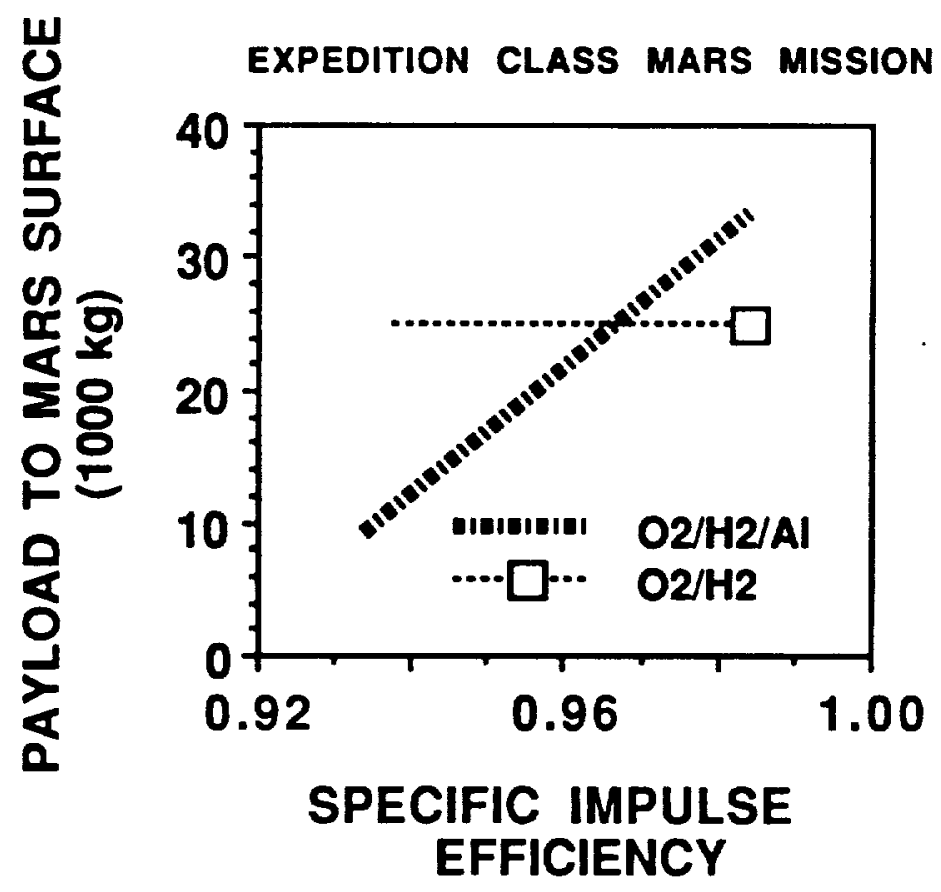

Figure 10. Payload vs. Isp Efflciency 


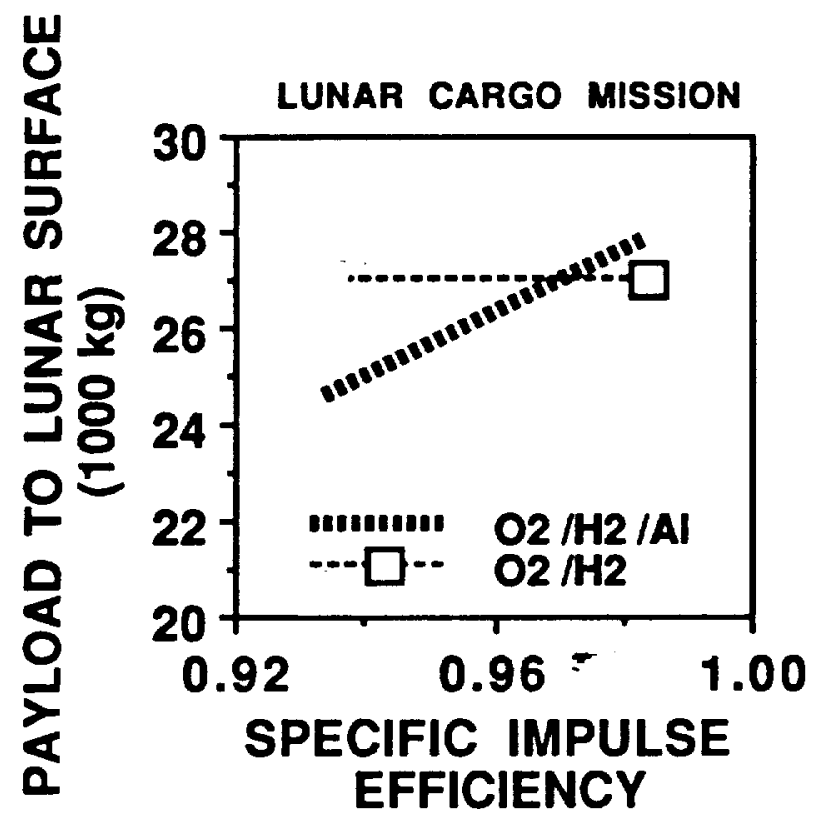

Figure 11. Lunar Excursion Vehicle Payload vs. Isp Efflclency

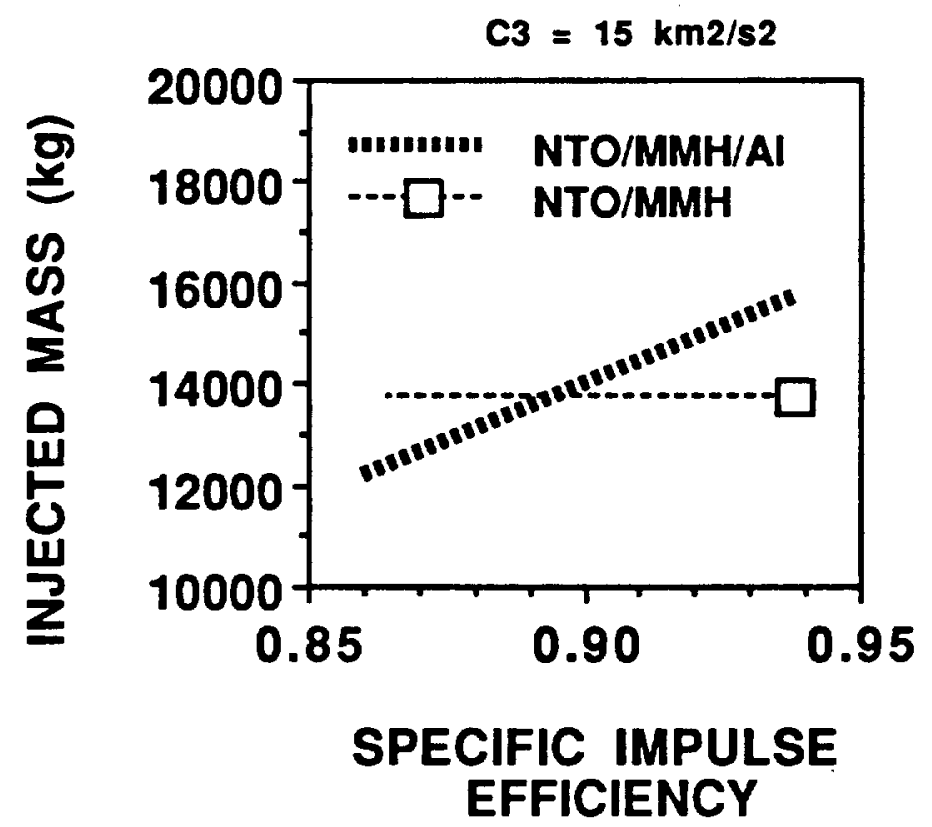

FIgure 12. NTO/MMH/Al Injected Mass vs. Isp Efflciency 


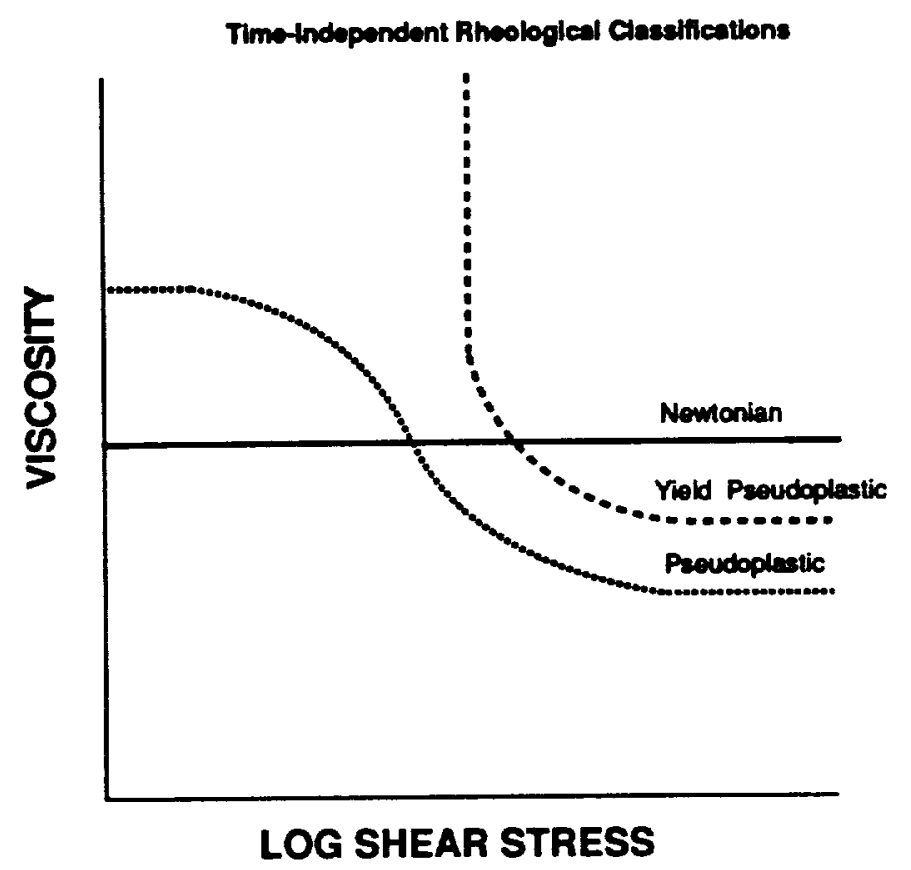

Figure 13. Viscosity vs. Shear Stress

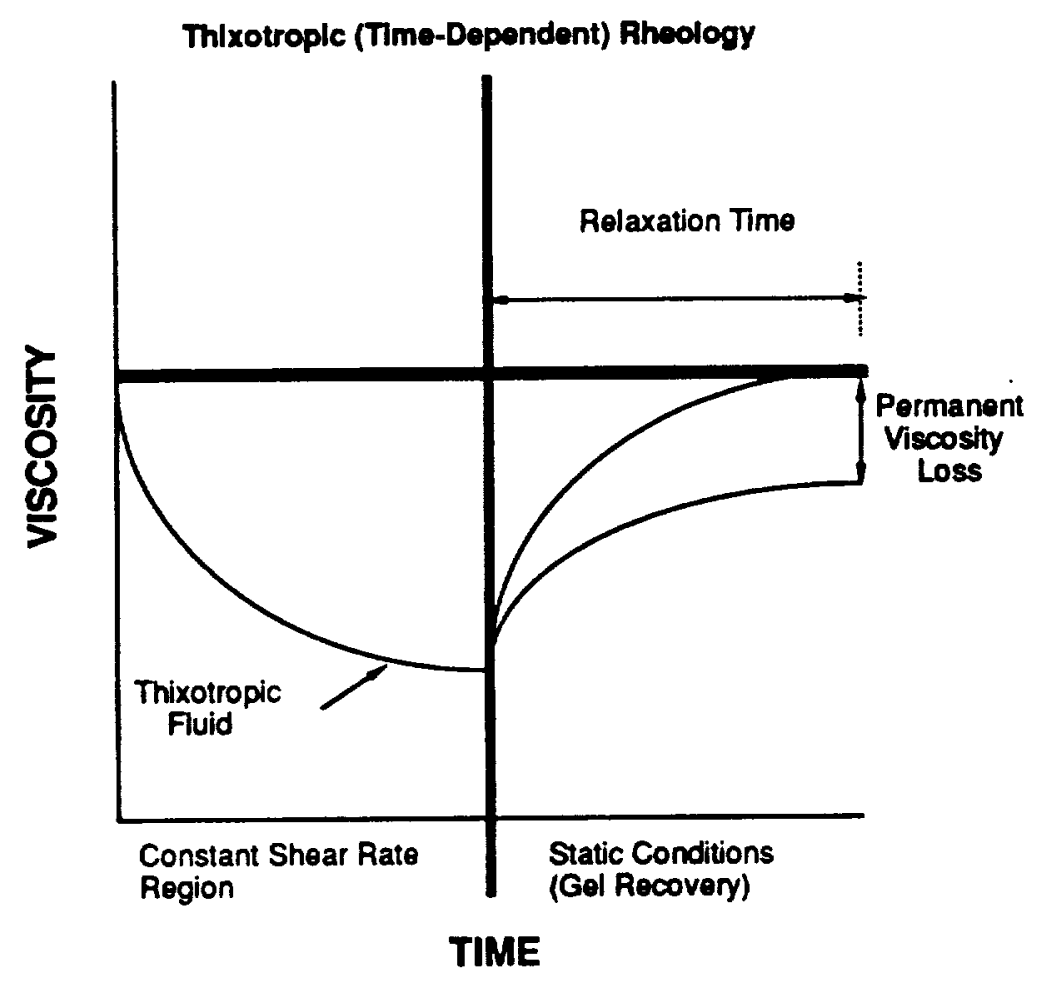

Flgure 14. Vlscoelty ve. Time 


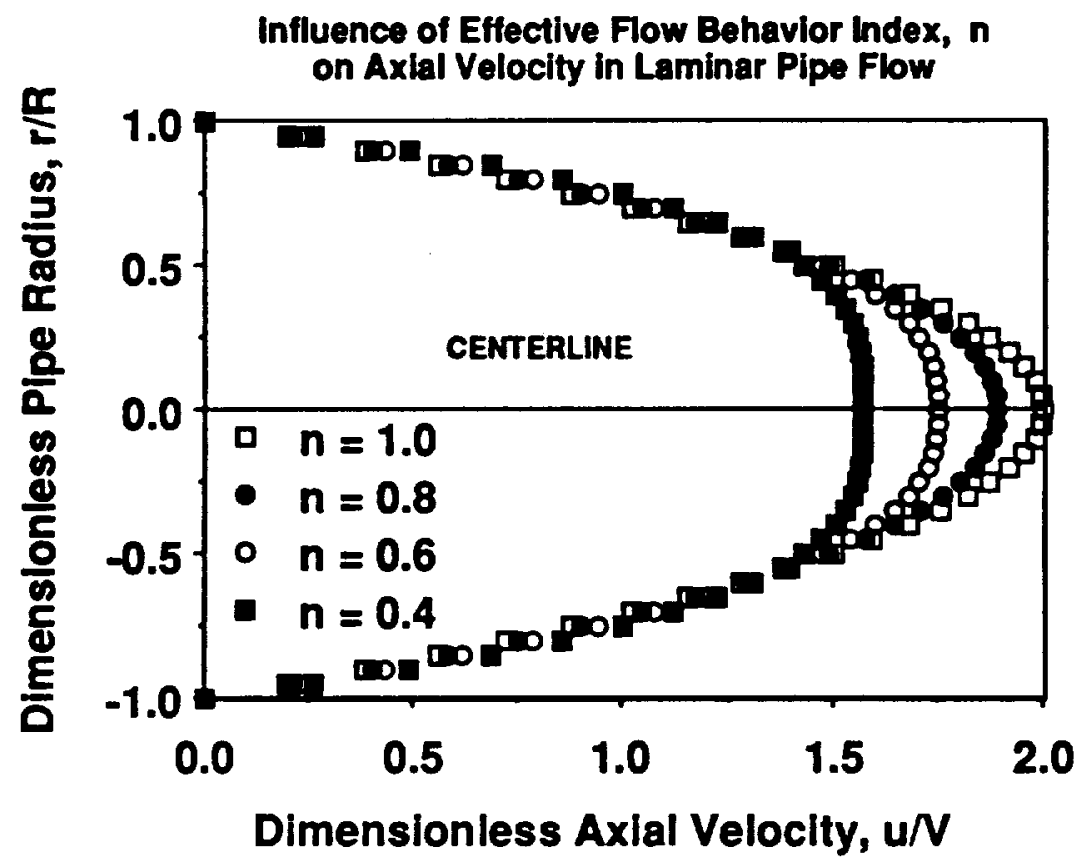

Figure 15. Pipe Radius vs. Axlal Velocity

\section{Pressure Drop Characteristics of a Shear}

Thinning Metallized Propellant

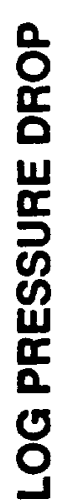

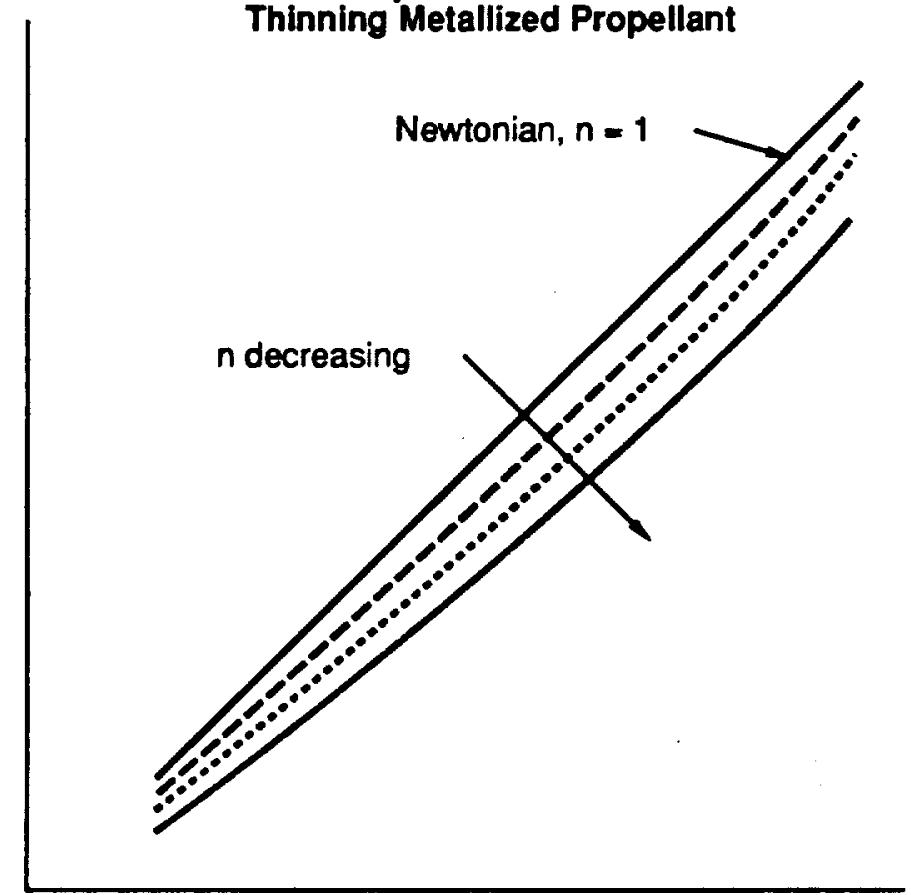

LOG VOLUMETRIC FLOW RATE

Figure 16. Pressure Drop vs. Flow Rate 


\begin{tabular}{|c|c|c|}
\hline \multicolumn{2}{|c|}{ REPORT DOCUMENTATION PAGE } & $\begin{array}{l}\text { Form Approved } \\
\text { OMB No. } 0704-0188\end{array}$ \\
\hline \multicolumn{3}{|c|}{ 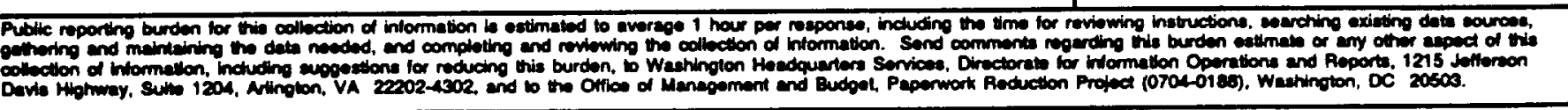 } \\
\hline 1. AGENCY USE ONLY (Leave blank) & \begin{tabular}{|l|l|} 
2. REPOAT DATE & 3. A \\
\end{tabular} & $\begin{array}{l}\text { 3. AEPOAT TYPE AND DATES COVERED } \\
\text { Technical Memorandum }\end{array}$ \\
\hline \multicolumn{2}{|c|}{$\begin{array}{l}\text { A TITLE AND 8UBTTtLE } \\
\text { Design Issues for Propulsion Systems Using Metallized Propellants }\end{array}$} & \multirow{2}{*}{$\begin{array}{l}\text { 5. FUNDING NUMBERS } \\
\text { WU }-506-42\end{array}$} \\
\hline \multicolumn{2}{|l|}{$\begin{array}{l}\text { C. AUTHOA(s) } \\
\text { Bryan Palaszewski }\end{array}$} & \\
\hline \multicolumn{2}{|c|}{$\begin{array}{l}\text { 7. PERFORMING OACANIZATION NAME(8) AND ADDRESS(ES) } \\
\text { National Aeronautics and Space Administration } \\
\text { Lewis Research Center } \\
\text { Cleveland, Ohio } 44135 \text { - } 3191\end{array}$} & $\begin{array}{l}\text { D. PERFOAMING OROANIZATION } \\
\text { REPORT NUMBER } \\
\text { E-6492 }\end{array}$ \\
\hline \multicolumn{2}{|c|}{$\begin{array}{l}\text { 9. SPONSORINO/MONTORINO AGENCY NAMES(S) AND ADDRESS(ES) } \\
\text { National Aeronautics and Space Administration } \\
\text { Washington, D.C. } 20546-0001\end{array}$} & $\begin{array}{l}\text { 10. SPONSOAING/MONTOOAINO } \\
\text { AOENCY REPORT NUMBER } \\
\text { NASA TM }-105190 \\
\text { AIAA - } 91-3484\end{array}$ \\
\hline \multirow{2}{*}{\multicolumn{3}{|c|}{$\begin{array}{l}\text { 11. BUPPLEMENTAAY NOTES } \\
\text { Prepared for the Conference on Advanced Space Exploration Initiative Technologies cosponsored by the AIAA, NASA, } \\
\text { and OAI, Cleveland, Ohio, September 4-6, 1991. Responsible person, Bryan Palaszewski, (216) 433-2439. }\end{array}$}} \\
\hline & & \\
\hline \multicolumn{2}{|c|}{$\begin{array}{l}\text { 12.. DISTAIBUTION/AVAILABILITY STATEMENT } \\
\text { Unclassified-Unlimited } \\
\text { Subject Category } 20\end{array}$} & 12b. DISTAIBUTION CODE \\
\hline \multicolumn{3}{|c|}{$\begin{array}{l}\text { 13. AOstRACT (Maximum } 200 \text { mords) } \\
\text { Metallized propellants are liquid propellants that contain metal particles. These particles are suspended in a gelled fuel or } \\
\text { oxidizer. Aluminum is used as the metal additive. The addition of metal to conventional propellants can increase their } \\
\text { specific impulse }\left(\mathrm{I}_{\mathrm{sp}}\right) \text { and their density over conventional propellants, and consequently, the payload delivered on Mars } \\
\text { and lunar transportation vehicles, Earth-to-Orbit vehicles and upper stages for robotic planetary missions. Gelled fuels } \\
\text { also provide increased safety during accidental propellant leakage or spills. To take full advantage of these potential } \\
\text { performance increases, there are changes that must be made to the vehicle design. This paper will discuss the differences } \\
\text { between metallized propellant and traditional liquid propellants and their effect on the propulsion system design. These } \\
\text { differences include the propellant density, mixture ratio, engine performance and propellant rheology. Missions related to } \\
\text { the Space Exploration Initiative are considered as design examples to illustrate these issues. }\end{array}$} \\
\hline
\end{tabular}

14. SUBJECT TERMs
Systems analysis; Liquid rocket propellants; Metal propellants; Liquid propellant rocket engines; Mission planning; Upper stage rocket engines; Manned Mars missions; Launch vehicles

17. SECURTY CLASSIFICATION of REPOAT Unclassified

19. SECURTY CLASSIFICATION OF THIS PACE Unclassified
19. SECURTY CLASSIFICATION OF ABSTAACT Unclassified

\section{PRICE CODE}

20. LIMITATION OF ABSTRACT Standard Form 208 (Rov, 2-89) Preecorbed by AMSI Sid. 239-18 298-102 
National Aeronautics and Space Administration

Lowis Reaearch Center

Cleveland, Ohio 44135

Ombiet Businew

Penelty for Prtrute Une 5300
FOUnTH CLASS Mall

ADDRESS CORRECTION REOUESTED
|||| $\mid$

Nalional Aeronaulics and

Space Adininisiration

NASA 451 